PERO TABAK, M.Sc.

E-mail:ptabak@fpz.hr

Council of Postal Services

Martićeva 11, HR-10000 Zagreb, Republic of Croatia

TOMISLAV KLJAK, M.Sc.

E-mail: tomislav.kljak@fpz.hr

University of Zagreb,

Faculty of Transport and Traffic Sciences

Vukelićeva 4, HR-10000 Zagreb, Republic of Croatia
Transport Engineering

Preliminary Communication

Accepted: Sep. 10, 2008

Approved: Oct. 22, 2009

\title{
TRAFFIC FLOWS MODEL OF POSTAL ITEMS BASED ON INPUT-OUTPUT DEMANDS IN THE PUBLIC POSTAL NETWORK: CASE STUDY OF CROATIA
}

\begin{abstract}
This paper presents the method for developing matrix model of postal traffic flows (ordinary communication items) in public postal network according to volume and different end-to-end (E2E) processes, which can be used for selecting of relevant model for accessing the public postal network. The presented traffic matrix model can be adjusted after the measurement of real volumes and selecting the numbers of different E2E processes (according to geographical input-output request). During the simulation of the model it could be possible to detect the optimal solution for accessing the public postal network.
\end{abstract}

\section{KEY WORDS}

traffic modelling, postal services, access to the public postal network

\section{INTRODUCTION}

The EU Postal Directive presumed access to the public postal network as the major tool for liberalization of the postal market. Therefore, the member states have obligation to set up the regulation for accessing the public network for all customers (bulk mailers, consolidators of mail from customers, other providers, etc.) on the principles of transparency and non-discrimination, with regard both to the tariffs and to the associated conditions.[2]

This paper is the middle part of a trilogy, which considers access to the public postal network from three aspects: the regulatory, the technological and the economic. The first paper: Conceptual technological framework for access to the postal public network [9], took into consideration the Croatian regulatory frame which is not fully compatible with the European regulatory frame. Therefore, according to Postal Di- rectives, the paper proposed for the good European regulatory practice and Croatian specific characteristics of the public postal network, the locations of access points (points which separate upstream and downstream processes) and possible sorting solutions (which avoid costs of upstream activity) for sustainable Croatian regulatory model for accessing the public postal network.

According to the new concept of price formation for universal services (discounts according to the amount of postage vs. discount according to the avoided costs in full value chain of single piece tariff, also known as worksharing) [10], this paper proposed a traffic matrix model of correspondent mail in public postal network which will show or indicate cross-subsidies in postal activities according to local, regional and intercity traffic. The traffic model, once established, will give opportunity for the distribution of the total costs of public postal network through all the parts of the value chain (next paper) and, according to those results, for the recalculation of tariffs for the access to the public postal network. The tariff of the universal postal service will be cost-oriented, affordable, transparent and non-discriminatory.[2]

The paper presents the conceptual proposition for the creation of a traffic matrix model of the correspondent mail in the public postal network, with the aim to identify major geographical distribution routes of mail in the postal network according to inputs (location of acceptance point) and consumer demands for outputs (location of delivery point). For the purpose of easier understanding of abstract traffic matrix model, some relevant data were taken from the Annual report of the Croatian Post for 2006, results of measuring in one sorting (postal) centre and the actual structure of the Croatian public postal network. All input data in the matrix model (which was created in standard software 
application - spreadsheet) can be changed after having measured the real quantities, while the results of the traffic distribution in the matrix (after costs results, too) are shown automatically.

\section{STRUCTURE OF VALUE CHAINS ACCORDING TO INPUT-OUTPUT DEMANDS IN PUBLIC POSTAL NETWORK}

For proper understanding of the traffic matrix model in the public postal network, it is necessary to point out the differences in the technological process between the conveying packages and the correspondent mail, as well as registered and ordinary mail. This paper presents only the traffic model of ordinary correspondent mail. Also, it is important to point out that the national postal operator (NPO) is responsible for the creation of technological process, as well as the definition of the full value chain. For this reason, this traffic matrix model is built on the generally accepted theory of postal traffic.

The general postulate for the price of universal postal services is a uniform tariff for all users, regardless of their geographical location. It is obvious that the costs of each postal service are not equal and it is natural for all the entrepreneurs to try to identify the real location of costs for every item. Therefore, a full value chain model is created, which will show full end-to-end process (E2E) and, at the same time, the

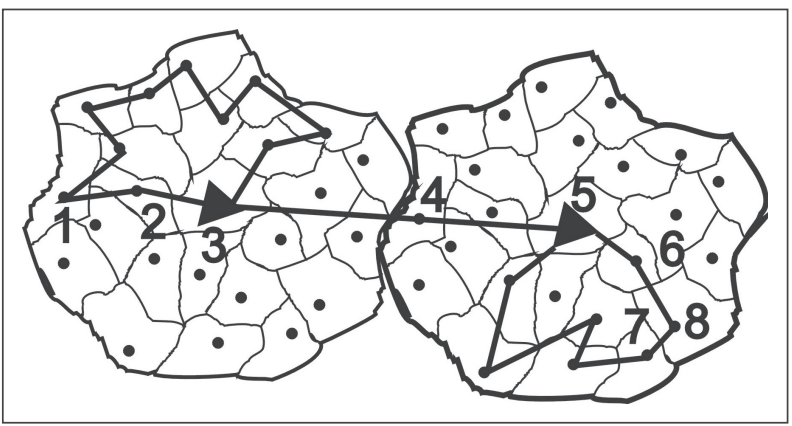

Figure 1 - Full technological process (full value chain) in public postal network most common partial E2E processes because most items passed through the partial E2E processes, but the questions are how many items and through which parts of the value chain.

Mail items are accepted in the geographical area of postal office (PO) (1) through PO boxes and other PO premises or, additionally in rural area, via postmen and postmasters. Concentration is the next process where furgons clear postal items from POs which are in the geographical area of a relevant sorting centre (2). Sorting mail for other inward sorting centres in the network is the next process (3). The transportation process from outward to inward sorting centres (4) follows. Next is the sorting process according to POs which are in the geographical area of the inward sorting centre (5) and diffusion (transporting) to the delivery POs (6). At the destination PO, if necessary, first the sorting of postal items according to the delivery area (last mile) is carried out (7), and then delivering of postal items to the address via postmen or through other postal premises (8).

All the postal items do not pass the full process. For example, items which were accepted (input) and are delivered (output) in the same geographical area of the PO will be only moved from the counter to the delivery department at the same post office (Figure 2a). For the next typical partial E2E process, items which were accepted in one PO and will be delivered to another PO but in the same geographical area of the sorting centre (SC) can be taken (Figure $2 \mathrm{~b}$ where input and output of the items are in the same SC area). The next two typical processes have the same input in the area of one (outward) SC and will be delivered in another (inward) SC. The difference between them is manifested in the different output. One is full E2E process because items must be delivered in the PO area which is not in the same geographical location where the inward sorting centre is located. The other process is still a partial E2E process because items will be delivered in the PO which is in the same area as the inward sorting centre and does not need to be diffused (Figure 2c\&d). Another reason why it is possible to make a difference between these processes lies in the

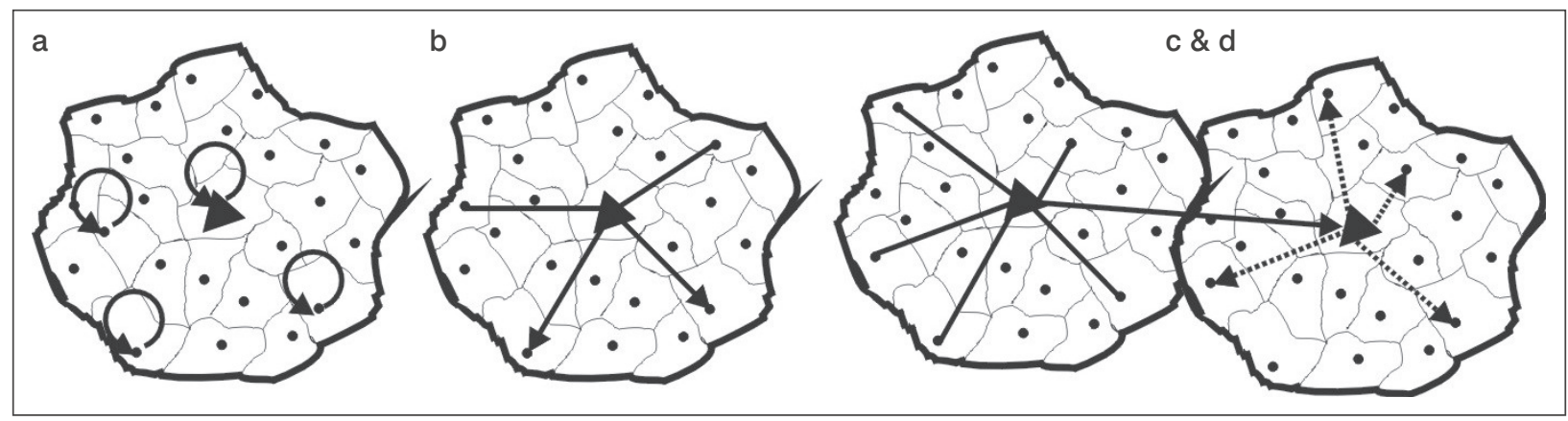

Figure 2abcd - Most common partial technological process according to input-output solutions in the public postal network 
fact that SC is usually located in the urban area where demand for postal services is significant and therefore the traffic model shows the precise quantities of items and its costs.

Figure 2a shows a partial process where input and output are in same PO area of acceptance (designated as loco traffic). In this case, there are only three chains: accepting, last mile sorting and delivery. In the next Figure (2b) it can be seen that input and output are in same area of SC (designated as regional traffic). Now there are more value chains: accepting, concentration, sorting to $\mathrm{PO}$, diffusion, last mile sorting and delivery. Figure 2c (without dot lines) shows when the inputs are in the area of outward SC and output is in $\mathrm{PO}$ which is in the same town where SC is established. In this case there are 6 value chains: accepting, concentration, sorting to PO, transport, last mail sorting and delivery. And the last Figure $2 \mathrm{~d}$ (with dot lines) presents the full eight-value chain. Both processes are shown in Figure 2c\&d and can be designated as intercity traffic.

\section{STRUCTURE OF INPUT-OUTPUT IN ONE VIRTUAL SORTING CENTRE}

The analyzed flow structure can be visualized and described by a virtual sorting centre and its input-output demands. The presented percentages are calculated according to the empirical data which were ob-

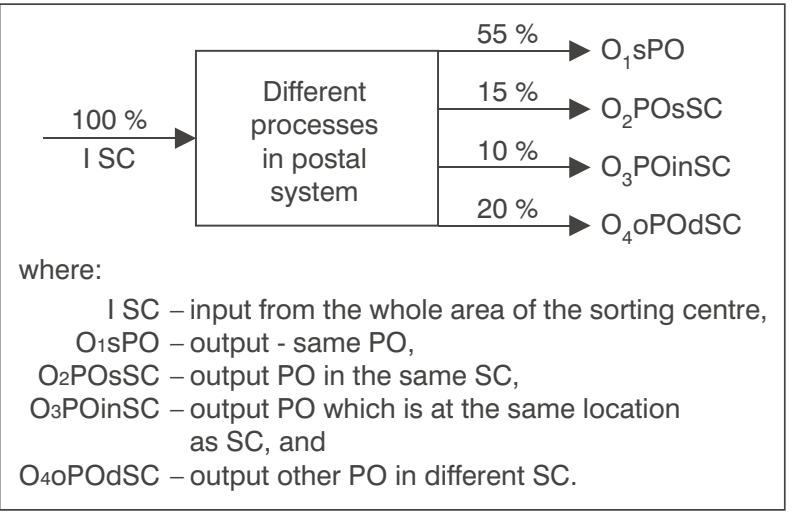

Figure 3 - Distribution of postal items according to different demands for output in one virtual SC tained from the counter software of automated sorting machine in one sorting centre.

Also, for better understanding, let us assume that there are 330 million ordinary communication items in postal traffic during the year and, for simplicity of the model, let us assume that there are only 5 sorting centres in Croatia; Zagreb, Varaždin, Osijek, Rijeka and Split [1]. In this matrix of the traffic model it is assumed that all SCs have the same distribution according to different demands for output from postal network.

Table 1 gives the distribution of the total ordinary communication items according to the assumed percentage from the first column and the total items which every SC clears from their area (row). From the Table it is evident that the total number of items which remain in same SC area is 231 million (181.5 million in local traffic and 49.5 million in regional traffic) and only 99 million will be dispatched in the postal network to other SCs (intercity traffic).

Now, using the data for outputs 3 and 4 in Table 1, it is possible to create a new matrix (which is directly connected with the matrix in Table 1) and represents the number of items which each SC dispatches to all the other SCs in the public postal network. The data will represent how many items each SC dispatches in the postal network, but at the same time, how many items are dispatched to the $\mathrm{PO}$ in the same location as SC (output 3) and to other POs in the remaining PS area (output 4). In this paper, only one Table is given as the sum of outputs 3 and 4 .

The figures given in Table 2 lead now to a conclusion that SC Zagreb dispatched to SC Rijeka 21 million items and, vice versa, SC Rijeka dispatched to SC Zagreb 8.69 million items during one year. It is possible to make the same conclusions for all the other sorting centres, but it is common that SCs with the biggest inputs dispatch more items to other SCs than they had sent. For proportional calculation of the quantities which each outward SC dispatches to each inward SC, here the proportion from the total number of inward SCs is taken and the total number of items in the network without (minus) number of items of outward SCs. This proportion is multiplied by the sum of output 3 and/or 4 of outward SC. The same procedure is done for each SC.

Table 1 - Distribution of postal items according to different output demands

\begin{tabular}{||c|c|c|c|c|c|c||}
\hline \hline Distribution & SCZagreb & SCRijeka & SCVarazdin & SCSplit & SCOsijek & TOTAL \\
\hline \hline & $\mathbf{2 1 0}$ & $\mathbf{4 0}$ & $\mathbf{3 3}$ & $\mathbf{3 0}$ & $\mathbf{1 7}$ & $\mathbf{3 3 0}$ \\
\hline O1 $\mathbf{5 5} \%$ & 115.5 & 22 & 18.15 & 16.5 & 9.35 & 181.5 \\
\hline O2 - 15\% & 31.5 & 6 & 4.95 & 4.5 & 2.55 & 49.5 \\
\hline O3 $-\mathbf{1 0} \%$ & 21 & 4 & 3.3 & 3 & 1.7 & 33 \\
\hline $\mathbf{2 0} \%$ & 42 & 8 & 6.6 & 6 & 3.4 & 66 \\
\hline
\end{tabular}

Source: According to data from the Annual Report of Croatia Post 2006 (quantities) and measurement at one sorting centre (as percents of distribution) 
Table 2 - Distribution of dispatched items in public postal network (from all outward SCs to all inward SCs)

\begin{tabular}{|c|c|c|c|c|c|c|}
\hline \multicolumn{7}{|c|}{ Dispatch outward SC for inward SC $(\mathrm{o} 3+\mathrm{o} 4)$} \\
\hline From & Total & SCZagreb & SCRijeka & SCVarazdin & SCSplit & SCOsijek \\
\hline SCZagreb & 63 & & 21.00 & 17.33 & 15.75 & 8.93 \\
\hline SCRijeka & 12 & 8.69 & & 1.37 & 1.24 & 0.70 \\
\hline SCVarazdin & 9.9 & 7.00 & 1.33 & & 1.00 & 0.57 \\
\hline SCSplit & 9 & 6.30 & 1.20 & 0.99 & & 0.51 \\
\hline SCOsijek & 5.1 & 3.42 & 0.65 & 0.54 & 0.49 & \\
\hline Total arrival & 99 & 25.41 & 24.19 & 20.22 & 18.48 & 10.71 \\
\hline
\end{tabular}

For example, to proportionally calculate how many items SC Zagreb dispatched to SC Split, this could be done by taking the proportion between the total items of SC Split and by dividing it with the total number of items in the network without the number of SC Zagreb. This proportion must be multiplied by the sum of output 3 and 4 of SC Zagreb (all data are from Table 1). Also, separate calculations for output 3 and output 4 are necessary if separate results are to be obtained when starting to calculate numbers of items for delivery in different POs (PO in the same location like SC and others).

Furthermore, there is a specific formula for calculating the number of items which are dispatched from one SC to another:

$$
D_{A \rightarrow B}=\frac{N_{B}}{\sum_{i=1}^{n} N_{i}-N_{A}} \cdot\left(N_{O_{3} A}+N_{O_{4} A}\right)
$$

where:

$D_{A \rightarrow B}$ - number of items which one SC (A) dispatches to another (B),

$\mathrm{N}_{\mathrm{A}}$ - total number of items accepted in the dispatching SC,

$\mathrm{N}_{\mathrm{B}}$ - total number of items accepted in the arriving $\mathrm{SC}$,

$\mathrm{N}_{\mathrm{i}}$ - total number of items accepted in SCs (Varaždin, Rijeka, Zagreb, Split, Osijek),

$N_{O_{3} A}$ - number of items which are output of the dispatching SC (A) for POs located in the same location as the arriving SC,

$N_{O_{4} A}$ - number of items which are output of the dispatching SC (A) for POs located in different locations than the arriving SC.

For example, calculation of the number of items which SC Zagreb dispatches to SC Split:

$$
\begin{aligned}
& D S C_{Z} \rightarrow S C_{S}= \\
& =\frac{N_{S C_{Z}}}{\left(N_{S C_{Z}}+N_{S C_{S}}+N_{S C_{R}}+N_{S C_{V}}+N_{S C_{O}}\right)-N_{S C_{Z}}} . \\
& \quad \cdot\left(N_{O_{3} S C_{Z}}+N_{O_{4} S C_{Z}}\right)=
\end{aligned}
$$

$$
\begin{aligned}
& =\frac{30}{(210+30+40+33+17)-210} \cdot(21+42)= \\
& =\frac{30}{330-210} \cdot 63=15,75[\text { million items per year] }
\end{aligned}
$$

For the "extended" matrix model (the matrix model which has different distribution percentages for every SC) designers must insert new columns before each column (as extension of Table 1) for every SC and note percentages after measuring the real quantities. In this paper it is assumed that the percentages of output distribution are the same for all SCs (for exact figures field measurements must be done. For this paper input data were taken from internal surveys in one sorting centre).

It is obvious from figures in Table 2 that $\mathrm{SC}$ with the largest input traffic dispatches larger numbers of items in the network than other SCs. On the contrary, SC with smaller input traffic has higher number of items which arrived to it, especially comparing its input with output. Therefore, input-output traffic model in the public postal network has to be considered from two aspects for each SC. Inputs of SC means inputs from customers and inputs from other SCs in the public postal network. On the other side, output means items for delivery to customers and at the same time dispatch to the network. This is the reason why each $\mathrm{SC}$ has a disproportion in quantities of accepted and delivered postal items against the whole public postal network which has the same result of input and output quantities. For the purpose of better understanding, let us graphically present the disproportion of input-output demands in this virtual sorting centre in different ways, one from the acceptance and the dispatch point, other from arrival and delivery point. ispraviti u slici u naslovu gore: acceptance (umjesto Accept) dispatch (umjesto dispach)

When sorting centre is observed in the network with asymmetric traffic, it is obvious that the same SC will reveal different ratio of inputs and outputs, which depends on the fact if the observation is from the acceptance and dispatch side or from the arrival and delivery side. For example, according to the introduced 


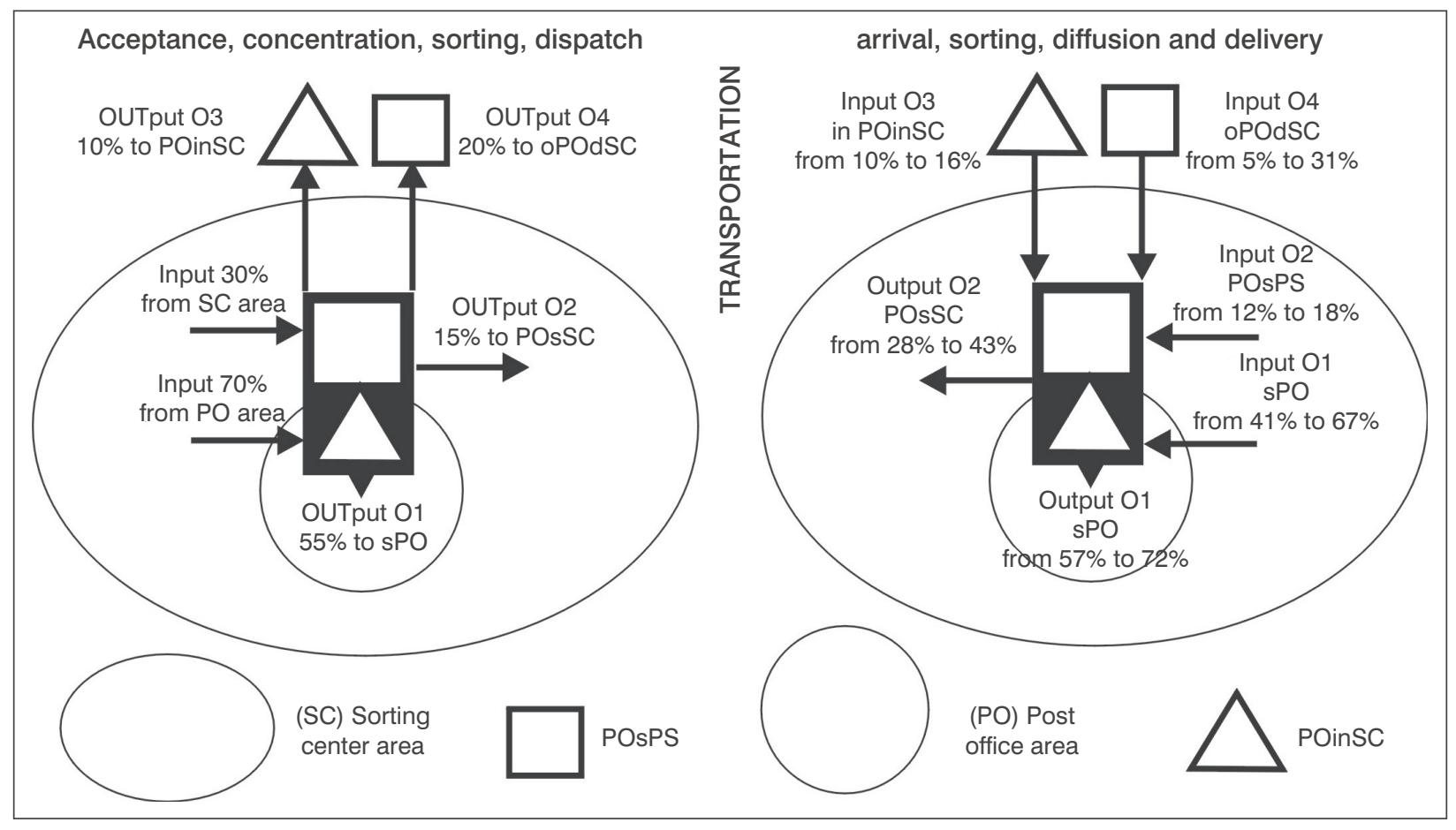

Figure 4 - The virtual sorting centre from two input-output aspects, acceptance and dispatch point vs. arrival and delivery point

traffic model, SC Zagreb has significant different distributions of input and output from acceptance side (let us say top-down method) then from the delivery side (let us say bottom-up method).

\section{INPUT-OUTPUT DEMANDS IN THE PUBLIC POSTAL NETWORK}

By looking throughout the traditional accounting method which public operators use to present their financial results and financial results of every SC, it can be seen that SC Zagreb has positive financial results but other SCs have not [1]. Thus, the question is why SC Zagreb always has the best financial results in the Annual Report? Is it because it has effective and efficient business activity, or else, because it has higher quantities of accepting items than quantities of the delivery items, which means most income from postage, less costs in the delivery phase?

Matrix in Table 3 represents the arrival quantities of items for the delivery in PO with the same location like the SC and in other PO. The number of items for delivery is the sum of items from acceptance in the same PO (output 1) plus results of distribution arrival items for PO at the same location as SC (output 3) and from other side, items from the SC area (output 2) plus results of distribution arrival items for $\mathrm{PO}$ in the SC area (output 4).

Figures in Table 3 show that in SC Zagreb 48.44 million items will be delivered throughout PO in SC area (31.5 million accepted in the same area) and
123.97 million items in PO Zagreb (115.5 million accepted). According to the 2006 Annual Report and the traditional accounting method, SC Zagreb has an income from postage of 210 million items but, on the other hand, it must deliver 38 million items less than it accepts, and therefore the best business results of SC Zagreb compared to other sorting centres are not surprising.

Figure 5 shows that SCs other than SC Zagreb have more items for delivery than acceptance. If the fact is ignored that other SCs have a bigger area (approximately twice the area of SC Zagreb), and the fact

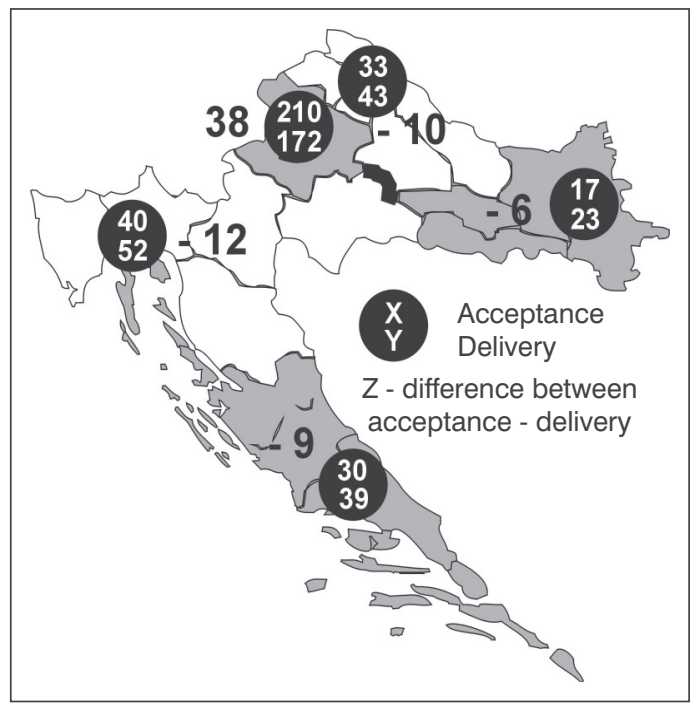

Figure 5 - Discrepancy between annual numbers of accepted and delivery items 
Table 3 - Annual numbers of items which will be delivered in PO with same location as SC and in PO throughout SC area

\begin{tabular}{|c|c|c|c|c|c|c|}
\hline \multicolumn{7}{|c|}{ Delivery in PO throughout $\mathrm{SC}$ area $(\mathrm{O} 2+$ result of distribution $\mathrm{O} 4)$} \\
\hline & SCZagreb & SCRijeka & SCVaraždin & SCSplit & SCOsijek & Total \\
\hline SCZagreb & 31.50 & 14.00 & 11.55 & 10.50 & 5.95 & 73.50 \\
\hline SCRijeka & 5.79 & 6.00 & 0.91 & 0.83 & 0.47 & 14.00 \\
\hline SCVaraždin & 4.67 & 0.89 & 4.95 & 0.67 & 0.38 & 11.55 \\
\hline SCSplit & 4.20 & 0.80 & 0.66 & 4.50 & 0.34 & 10.50 \\
\hline SCOsijek & 2.28 & 0.43 & 0.36 & 0.33 & 2.55 & 5.95 \\
\hline Total & 48.44 & 22.12 & 18.43 & 16.82 & 9.69 & 115.50 \\
\hline \multicolumn{7}{|c|}{ Delivery in $\mathrm{PO}$ which is in same location like $\mathrm{SC}(\mathrm{O} 1+$ result of distribution $\mathrm{O} 3)$} \\
\hline & SCZagreb & SCRijeka & SCVaraždin & SCSplit & SCOsijek & Total \\
\hline SCZagreb & 115.50 & 7.00 & 5.78 & 5.25 & 2.98 & 136.50 \\
\hline SCRijeka & 2.90 & 22.00 & 0.46 & 0.41 & 0.23 & 26.00 \\
\hline SCVaraždi & 2.33 & 0.44 & 18.15 & 0.33 & 0.19 & 21.45 \\
\hline SCSplit & 2.10 & 0.40 & 0.33 & 16.50 & 0.17 & 19.50 \\
\hline SCOsijek & 1.14 & 0.22 & 0.18 & 0.16 & 9.35 & 11.05 \\
\hline Total & 123.97 & 30.06 & 24.89 & 22.66 & 12.92 & 214.50 \\
\hline
\end{tabular}

that delivery is the most expensive value chain in the entire technological process, it is not surprising that other virtual sorting centres have negative financial results. Thus, financial results cannot be monitored according to financial results of each SC. Therefore, the proposal is to monitor traffic of items in four different value chains according to input-output demands in the public postal network. This result will show different costs for each partial and full value chain with the numbers of items in each chain and, if these two numbers are divided, cost for each item in four different processes can be concluded. The data will help in calculating the prices for different approaches to public postal network and, at the same time, in monitoring the influence of worksharing on incomes and costs.

The proposed traffic model matrix is necessary and the most important challenge for NPO because it has to be able to locate the cost for every part of the value chain. Not only for the proper calculation of the best price for access to the public postal network, but even for the trustworthy managing of the entire financial system as well. Therefore, it is necessary to perform exact traffic measurements of items in the public postal network according to the proposed traffic matrix model and to affirm real quantities in different partial and full E2E processes, as well as to identify the quantities in loco (same PO), regional (same SC) and intercity (different SC) traffic. On that basis, the NPO could be able to recalculate the cost-orientated price for each universal service.

\section{POSSIBLE ANNEXES FOR TRAFFIC MATRIX MODEL IN THE PUBLIC POSTAL NETWORK}

There are two possible annexes for the presented traffic matrix model with the aim of making a more reliable calculation of cost-oriented prices for universal postal services and the calculation of the avoided part of prices for accessing the public postal network. Both annexes are linked with the universal service obligation (USO) on the entire territory, with the possibility of real reaction to other providers which provide postal services only in the urban area, at the same time building parallel urban delivery network.

The first annex for the presented traffic matrix model can be the distinction between two locations where mail could be accepted (inputs). The items accepted in a PO area, which is not in the same location as SC, have to be concentrated (transported) from the remote $\mathrm{PO}$ area to the inward sorting centre. That cost is usually lower than for the items accepted in the PO area where the inward sorting centre is located. Also, according to the real measurement of traffic in one sorting centre, one third of all items must be concentrated from the remote PO area in the SC and other two thirds are accepted in the same location where the $\mathrm{SC}$ is situated. Therefore, during the development of a real traffic matrix model, the designers can take this fact into consideration.

The second annex has a direct link to the most expensive value chain link - delivery [12] which can be 


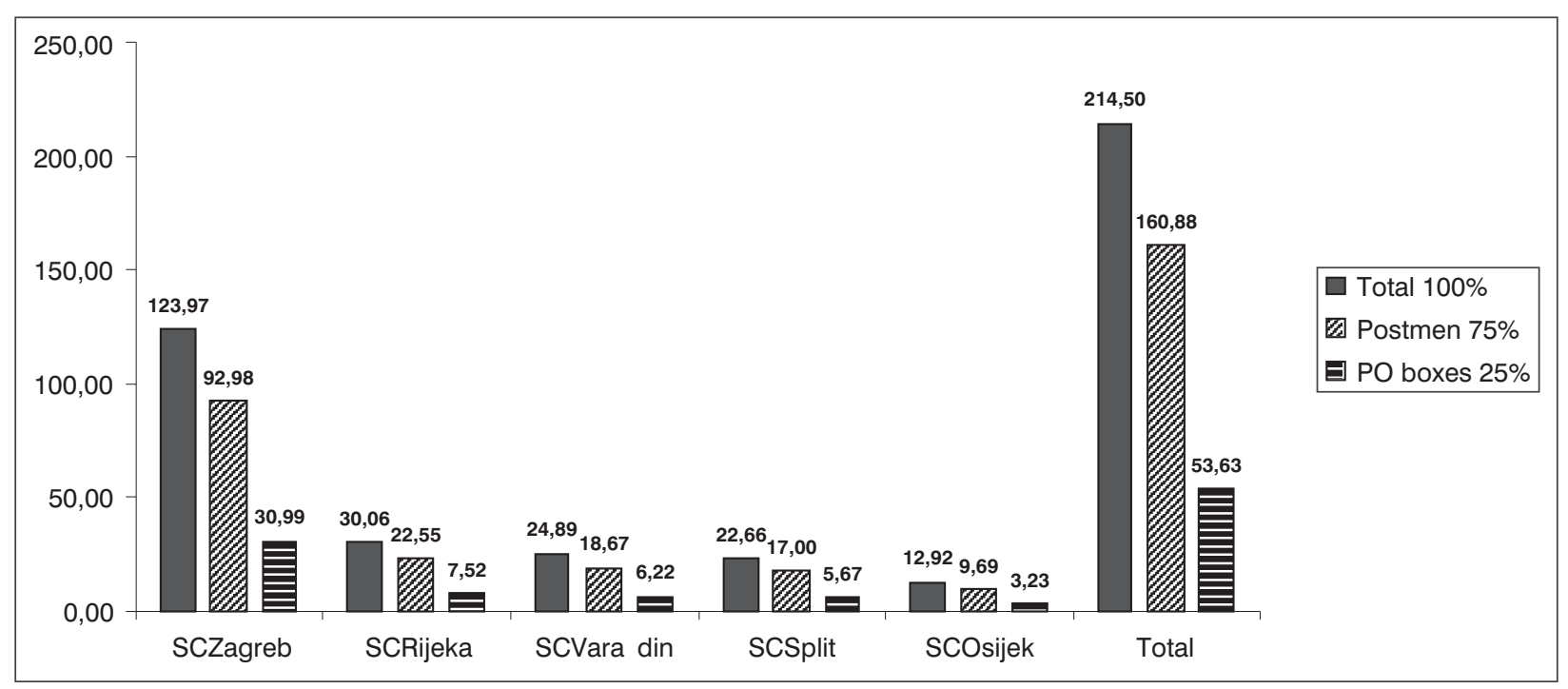

Figure 6 - Annual numbers of items which could be delivered via PO boxes and postmen in PO area in the same location as SC

performed in the PO throughout postal boxes or by postmen to home addresses. Of course, these costs are significantly different between delivery throughout postal boxes in PO and via postmen to home addresses. Table 4 gives the annual number of items delivered via postmen and $\mathrm{PO}$ boxes in $\mathrm{PO}$ area in the same location as $\mathrm{SC}$ according to the measuring in one sorting centre. From the total sum of items in the public postal network (330 million), 214.5 million items were delivered in PO with same location as PO and only 115.5 million were delivered in PO throughout $\mathrm{SC}$ area. It can also be seen that 71.5 million items were delivered throughout PO boxes without counting items which are delivered throughout $\mathrm{PO}$ boxes in other PO in the SC area.

NPO has strong competition in the urban area but in rural area it has no competition. Therefore, it is in common interest for the NPO and the State (because State accepts and ratifies universal service obligation) to find suitable tariff model for access to the public network, both for the urban and the rural area. The main challenges for selecting the best solutions are how to reduce the prices for access in the urban area, but at the same time, to find an acceptable model in the rural area (not only with the price policy), for example, by reengineering the public postal network, introducing new premises, contracting postal offices and other well-know modalities.

Also, this matrix model of traffic in the public postal network can be integrated with costs of each value chain (next paper). So, NPO has the opportunity to test a variety of solutions of tariff models for different scenarios with the aim of selecting the best tariff model for access to the public postal network in urban and rural area regarding transparent and non-discriminatory conditions. In other words, NPO has the opportunity to give proper and adequate answer to pro- viders who provide services only in the urban area and safeguard universal service obligation in the rural area.

Figures in the paper indicate the need for exact measuring of traffic of the postal items in public postal network. With this measurement it is possible to ascertain real quantities of postal items in different E2E processes and, according to those figures it is possible to ascertain the number of items in every chain of the full value chain. With this traffic and costs matrix model and its essential results it could be possible to decide on the appropriate strategy for access to the public postal network and to make many other necessary business decisions.

\section{CONCLUSION}

According to Postal Directives, the NPO shall ensure that other providers and customers have downstream access to the public postal network, and for universal service providers, access to the public postal network in the same way and conditions in which NPO use postal premises for itself (doctrine of essential facilities). Also, NPO shall make to public the conditions and prices for access to the public postal network in respect to single piece tariff and avoiding costs in upstream process (worksharing). All prices must be cost-oriented, affordable, transparent and non-discriminatory.

For the appropriate decision of price rate for access in different locations of the public postal network (upstream), the NPO must complete the measuring of postal traffic in the entire postal network and insert the results in the traffic matrix model which will be based on the proposed matrix model and designed according to its business activity. According to these re- 
sults from the traffic matrix model in public postal network and afterwards, according to the allocation of all the costs in the full value chain (next step), the NPO will have the opportunity to determine the quantities and costs for each postal service with the structure of partial and full E2E processes and its cross-subsidies. With those two connected matrix models (traffic and costs), the NPO has the potential to simulate different solutions for selecting of acceptable prices for access to the public postal network which correlate with its total incomes.

Therefore, this paper presents the method for the development of the traffic matrix model of ordinary communication items in the Croatian public postal network according to actual traffic quantities and different end-to-end processes. The usage of this traffic matrix model gives the opportunity to simulate various solutions and bring the necessary decisions for the optimization of the public postal network, especially in rural areas.

\author{
Mr. sc. PERO TABAK \\ E-mail:ptabak@fpz.hr \\ Vijeće za poštanske usluge \\ Martićeva 11, 10000 Zagreb, Republika Hrvatska \\ Mr. sc. TOMISLAV KLJAK \\ E-mail: tomislav.kljak@fpz.hr \\ Sveučilište u Zagrebu, Fakultet prometnih znanosti \\ Vukelićeva 4, 10000 Zagreb, Republika Hrvatska
}

\section{SAŽETAK}

\section{MODEL PROMETNIH TOKOVA OBIČNIH POŠTANSKIH POŠILJAKA PREMA ULAZNO-IZLAZNIM ZAHTJEVIMA U JAVNOJ POŠTANSKOJ MREŽI: PRIMJER SLUČAJA U HRVATSKOJ}

U radu je prikazana metoda za izradu matričnog modela prometa običnih pismovnih pošiljaka u poštanskoj mreži $R H$ sukladno količini prometa $i$ različitim „end-to-end“ (E2E) procesima u cilju izrade relevantnog pristupa javnoj poštanskoj mreži. Predočeni okvirni matrični model može se usklađivati nakon obavljenog mjerenja i ustanovljavanja stvarnih veličina prometa s obzirom na prostorne zahtjeve glede ulaza, odnosno izlaza iz javne poštanske mreže te potom i simulirati različita rješenja pristupa javnoj poštanskoj mreži.

\section{KLJUČNE RIJEČI}

modeliranje prometa, poštanske usluge, pristup javnoj poštanskoj mreži

\section{LITERATURE}

[1] Annual Financial Report of Croatian Post for 2006, Zagreb, 2007

[2] Directive 2008/6/EC: Official Journal of the European Union. L52, pp 15

[3] Kljak, T., Grgurević, I., Vujić, M.: Effects of Implementing e-Services and Telematic Aplications in Postal Items Delivery. TST Conference- Advances in Transport Systems Telematics, Katowice, 2008.

[4] Lisec, A., Rosi, B., Kavran, Z.: Holistic Thinking Approach: Case Study of Post Network in Slovenia, Promet-Traffic\&Transportation, Vol. 20, No. 2, 2008, pp 79-86

[5] Main Developments in the Postal Sector (2004-2006), WIK Consult GmbH - May 2006

[6] Reports EC to the Council and the European Parliament , COM/2006/595, COM/2006/594

[7] Study on the Conditions Governing Access to Universal Postal Services and Networks, CTcon, July 2001

[8] Study on the Evolution of the Regulatory Model for European Postal Services, Wik-Consult - July 2005

[9] Tabak, P.: Koncept tehnoloških modela pristupa javnoj poštanskoj mreži, Suvremeni promet, Zagreb (in print)

[10] Tabak, P.: Pregled prijedloga treće Poštanske direktive EU nakon prvog čitanja, Pošta, Vol. 2, No. 5, 2007.

[11] The Impact on Universal Service of the Full Market Accomplishment of the Postal Internal Market in 2009, PricewaterhouseCoopers, May 2006

[12] Walsh, T.: The European Mail Manifesto, Postal User's Group, 2006.

\section{DISCLAIMER}

The thesis and the conclusions presented in this paper do not represent the official standpoint and opinion of the Council for Postal Services in RH. 